\title{
ぜい性材料における破壊じん性とき裂形態の関係†
}

\author{
田中 \\ 學*

\section{Relationship between Fracture Toughness and Crack Morphology of Brittle Materials}

by

\author{
Manabu TANAKA*
}

\begin{abstract}
A theoretical analysis of crack morphology based on the fractal geometry was made to derive an equation correlating the fractal dimension of crack, $D$ " (the fractal dimension of crack profile in the two dimensional plane, $1<D$ " $<2$ ) with the fracture toughness, $K_{\mathrm{IC}}$. The fracture toughness, $K_{\mathrm{I} C}$, can be expressed as a following function of $D^{\prime \prime}: \ln$ $K_{\mathrm{IC}}=1 / 2\left\{\ln \left[2 \Gamma \mathrm{E} /\left(1-v^{2}\right)\right]-\left(D^{\prime \prime}-1\right) \ln r_{L}\right\}$, where $\Gamma$ is the work done in creating a unit crack surface, $E$ is Young's modulus, $v$ is Poisson's ratio, and $r_{L}$ is $r_{\min } / r_{\max }$, the ratio of the lower limit, $r_{\min }$, to the upper limit, $r_{\max }$, of the scale length, $r$, between which the crack exhibits a fractal nature $\left(r_{\min } \leqq r \leqq r_{\max }\right)$. The relationship between the indentation fracture toughness, and the fractal dimension of crack was then examined on various specimens of oxide, carbide and nitride ceramics and a hard metal.
\end{abstract}

Key words : Fracture toughness, Crack morphology, Fractal dimension, Brittle materials, Indentation fracture

\section{1 緒言}

Mandelbrot $5^{11}$ が衝撃破壊させた鋼の吸収エネルギ 一と破面のフラクタル次元の関係を明らかにして以来, フラクタル幾何学の概念は材料工学分野にも応用され， 結晶粒界などの微細組織 2 ( ) や様々な破面 ${ }^{5) ~ 10)}$ のフラ クタル性が明らかにされている. Mecholsky $ら^{11)}$ と Milman ら ${ }^{12)}$ はアルミナとガラスセラミックスの破面に ついて調べ, 破面のフラクタル次元 $D^{\prime}\left(1 \leqq D^{\prime} \leqq 2\right)$ と破壊じん性 $K_{\mathrm{IC}}$ の実験結果を, $K_{\mathrm{I} C}=K_{0}+E a_{0}{ }^{1 / 2}\left(D^{\prime}-\right.$ $1)^{1 / 2}$ という関係式にあてはめている $\left(K_{0}\right.$ は $D^{\prime}=1$ の仮 想的な材料の $K_{I}$ 值, $E$ は縱弾性係数, $a_{0}$ は長さの単 位をもつパラメーター)。この関係式は破面のフラクタ ル次元の増加によってセラミックス材料の破壊じん性が 增加することを示す，また，き裂の屈曲（tilting）とね じれ（twisting）はぜい性材料の重要な強じん化機構の ひとつである.13), 14)

Hull $^{15), 16)}$ はエポキシ樹脂についての最近の研究で, 破面形成に及ぼすモード I 以外の変位様式の介在とき裂 屈曲の重要性を指摘し, 破面形成の機構を理論的なら びに実験的に考察している. Hull も指摘しているよう に, 破面の面積の増加は有効表面エネルギーの増加抢よ びき裂成長抵抗の増加に結びつくので，ぜい性材料にお けるき裂の形態と破壞じん性の間の定量的な関係を知る ことは, 工学的な観点からは重要である.

第二相粒子の分散, 粒界形状, 結晶粒径を含む微細 組織は，一般に金属材料の破面のフラクタル次元，機械 的性質および破壊機構に影響を及ぼす.9), 17) 20) しかし， これらの微細組織個々の影響はその寸法に依存し，ある 限られた尺度の範囲で支配的であることが分かってい
る. ${ }^{8), 99,18), ~ 19)}$ 延性的な金属材料と同様にセラミックスに おいても，材料の強度とじん性は微細組織によって大き な影響を受ける. ${ }^{13)},{ }^{14)}$ き裂のフラクタル次元で評価され るき裂の形態は微細組織の寸法によって影響されるの で，セラミックスにおいて測定されたき裂のフラクタル 次元がどの微細組織に関係するのかを知ることは重要で ある。

セラミックスの破壊じん性の評価には様々な方法が提 案されている. $\left.{ }^{14)}, 20\right), 21$ このうち, IF 法 (Indentation fracture method）は最も簡便な方法としてよく知られ ている. Hul1 $\left.{ }^{15)}, 16\right)$ にると, ぜい性材料の圧痕から生 ビるき裂はモードIだけでなく，モード血の変位様式も 含んでいるので，圧痕破壊の破壞じん性 $K_{C}$ は厳密には 平面ひずみ破壊じん性 $K_{\mathrm{IC}}$ ではない。しかし，IF 法には き裂形状（メジアンき裂あるいは表面型き裂）の確認が 困難な点もあるものの $\left.{ }^{22)}, 23\right)$ 小寸法の試料を用いて容易 に行うことができ, 微細組織の小部分の破壞じん性を測 定できる長所があり，一般にぜい性材料では $K_{C}$ 值と $K_{\mathrm{I} C}$ 值との間に一定の関係があることが知られてい る. ${ }^{20), 21)}$ したがって, IF 法による $K_{C}$ 值から破壞じん性 值 $K_{\mathrm{IC}}$ を十分に推定することができると考えられる. 本 研究では, はじめにフラクタル幾何学に基づいてぜい性 材料に打ける破面抢よびき裂形状の解析を行い，破面お よびき裂のフラクタル次元と破壊じん性 $K_{\mathrm{IC}}$ を関連づ ける理論式を導き出した。つぎ, 酸化物系, 炭化物系 および窒化物系のセラミックスなどを用いて IF 法によ って破壊じん性 $K_{C}$ を求め, ボックス・カウント法 (Box-counting method) $)^{24) ~ 26)}$ によって圧痕き裂のフラ クタル次元 $D$ ”評価した。これらの実験結果に, 
Mecholsky ら ${ }^{11)}$ が求めたセラミックスの破壊じん性值 $K_{\mathrm{I} C}$ と slit island 法による破面のフラクタル次元の值を含 めて $K_{C}$ と $D ”$ の関係を調べた。 そして， $D$ ”值から理論 式を用いて $K_{\mathrm{I} C}$ を推定する場合に影響を及ぼす因子につ いて検討した. さらに, フラクタル解析の測定尺度と， 結晶粒径やき裂長さなどの微細組織の寸法との関連につ いても調べた.

\section{2 フラクタル幾何学によるき裂形状の評価と破壊じん性}

Fig. 1 のような面積 $S$ のぜい性材料の破面を，一辺の 長さ $r$ の正方形で被覆することを考える. ${ }^{24) ~}{ }^{26)}$ 破面を完 全に被覆する正方形の数 $N$ は, 一般に破面のフラクタ ル次元 $D(2 \leqq D \leqq 3)$ によって正方形の寸法 $r$ と次式 で関係づけられる. ${ }^{24) \sim 26)}$

$$
N \propto r^{-D}
$$

もし，Fig. 2 に示すように，破面が測定尺度 $r_{\min }$ と $r_{\max }$ の間 $\left(r_{\min } \leqq r \leqq r_{\max }\right)$ でフラクタル性をもつなら ば, ${ }^{27)} r=r_{\max }$ では $N=1$ である.したがって, 式 (1) はつ ぎのように書き直される。

\section{破面の面積 $S$ は}

$$
N=\left(r / r_{\max }\right)^{-D}
$$

$$
S=N r^{2}=r^{2}\left(r / r_{\max }\right)^{-D} \quad\left(\mathrm{~m}^{2}\right)
$$

式 (3) で $r=r_{\max }$ とおくと，破面の投影面積 $S=S_{p}$ は 次式で与えられる.

$$
S_{p}=r_{\max }^{2} \quad\left(\mathrm{~m}^{2}\right)
$$

また, 式 (3) で $r=r_{\min }$ とすると, 真の破面面積 $S=S_{t}$ が求められて,

$$
S_{t}=r_{\min }^{2}\left(r_{\min } / r_{\max }\right)^{-D} \quad\left(\mathrm{~m}^{2}\right)
$$

ここで，無次元量である規準化した真の破面面積 $S^{\prime}=$ $S_{t} / S_{p}$ と規準化した $r$ の下限值 $r_{L}=r_{\min } / r_{\max }$ を定義すると,

$$
S^{\prime}=S_{t} / S_{p}=\left(r_{\min } / r_{\max }\right)^{2-D}
$$

$$
=r_{L}^{2-D}
$$

破面のフラクタル性を考慮した場合の，破面の形成 （き裂の成長）によるエネルギー解放率 $g$ は, 単位面積 の破面形成に必要な仕事（単位面積当たりの表面エネル ギー）「を用いて

$$
g=2 \Gamma S^{\prime}=2 \Gamma r_{L}^{2-D} \quad\left(\mathrm{~J} / \mathrm{m}^{2}\right)
$$

材料の平面ひずみ破壊じん性 $K_{\mathrm{I} C}$ は次式で表される。

$$
\begin{aligned}
K_{\mathrm{IC}} & =\left\{g E /\left(1-v^{2}\right)\right\}^{1 / 2} \\
& =\left\{2 E \Gamma r_{L}^{2-D} /\left(1-v^{2}\right)\right\}^{1 / 2}
\end{aligned}
$$

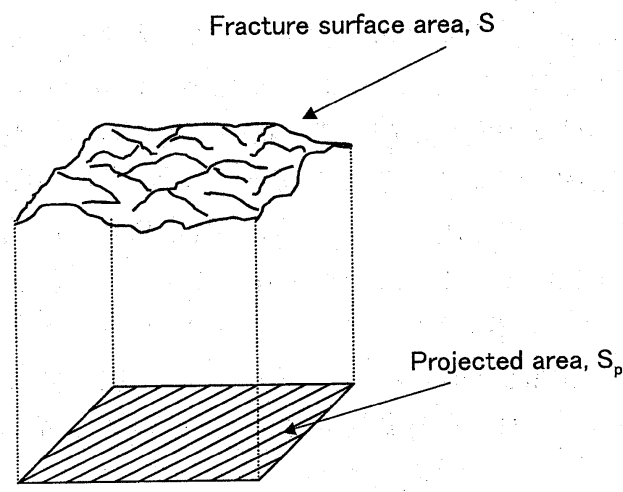

Fig. 1. Schematic illustration of fracture surface.
したがって, $K_{I C}$ の自然対数は,

$$
\ln K_{\mathrm{I} C}=1 / 2\left\{\ln \left[2 \Gamma E /\left(1-v^{2}\right)\right]-(D-2) \ln r_{L}\right\} \text { (9) }
$$

ここで， $r_{L}$ は破面のフラクタル解析によって求まる $r_{\min }$ と $r_{\max }$ から決定される. 上式の第二項 $(-(D-2)$ $\left.\times \ln r_{L}\right)$ は破面のフラクタル性による強じん化を表す.

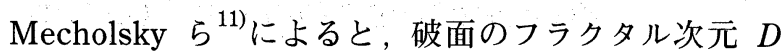
$(2 \leqq D \leqq 3)$ と slit island 法による破面のフラクタル次 元あるいは破面プロフィルのフラクタル次元 $D^{\prime}(1$ $\leqq D^{\prime} \leqq 2 ）$ の間には， $D-2=D^{\prime}-1$ という関係がある と考えられる。したがって，式 (9) は次のように書き換 えられる.

$$
\ln K_{\mathrm{IC}}=1 / 2\left\{\ln \left[2 \Gamma E /\left(1-v^{2}\right)\right]-\left(D^{\prime}-1\right) \ln r_{L}\right\} \text { (10) }
$$

もし, 破面のフラクタル次元 $(D)$ とき裂のフラクタ ル次元 $(D ", 1 \leqq D " \leqq 2)$ との間に同様の関係があるな らば，式 (10) で $D^{\prime}=D^{\prime \prime}$ とすれば次式が得られる.

$$
\ln K_{\mathrm{IC}}=1 / 2\left\{\ln \left[2 \Gamma E /\left(1-v^{2}\right)\right]-\left(D^{\prime \prime}-1\right) \ln r_{L}\right\}(11)
$$

Mecholsky $ら^{11)}$ と Milman $ら^{12)}$ はアルミナとガラ ス・セラミックスの破面を調べ, slit island 法で求めた 破面のフラクタル次元 $D$ ' と破壊じん性 $K_{\mathrm{I} C}$ との関係を $K_{\mathrm{I} C}=K_{0}+E a_{0}{ }^{1 / 2}\left(D^{\prime}-1\right)^{1 / 2}$ (ここで， $K_{0}$ は平坦な破面 に対する仮想的な $K_{\mathrm{I} C}$ の值， $a_{0}$ は長さの単位をもつパラ メーター）という式にあてはめた。しかし,本研究の理 論解析によると, 破壊じん性 $K_{\mathrm{I} C}$ と破面あるいはき裂 のフラクタル次元 $\left(D, D^{\prime}, D^{\prime \prime}\right)$ との間には，これと は異なる式 (9)〜 (11) の関係が成立するようである. これらの式で, 破面やき裂のフラクタル性による強じん 化の効果 (fractal toughening) は第 2 項 (- 0.5 (D - 2) $\ln r_{L}$ など）によよって表される。また， $r_{L}$ は破面ある いはき裂がフラクタル性を示す測定寸法の下限值 $r_{\text {min }}$ と上限值 $r_{\text {max }}$ の比 $r_{\min } / r_{\max }$ で, fractal toughening の 程度を表す。これらの值は破面やき裂のフラクタル解析 によって決められるが, 松岡らによると $r_{\min }$ の值はぜ い性材料の原子間隔の程度と推定され ${ }^{8)} r_{\text {max }}$ ' は結晶粒 径などの微細組織の寸法あるいはき裂や破面の寸法に関

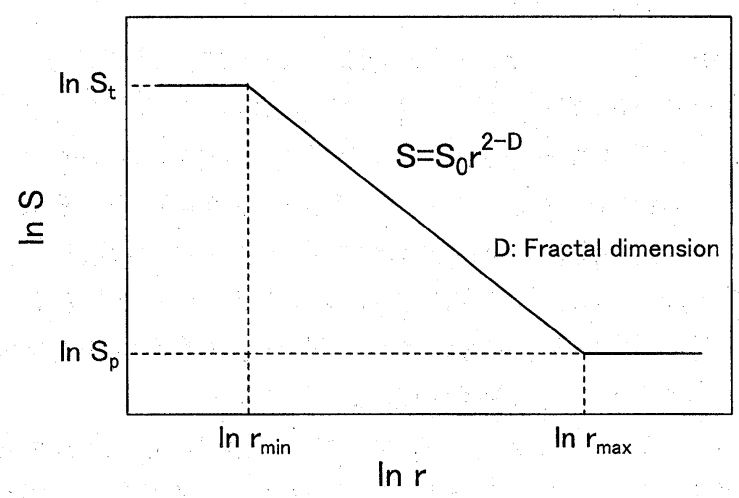

Fig. 2. Relationship between the fracture surface area, $S$, and the scale length of fractal analysis, $r$ [27] $\left(S_{p}:\right.$ the projected area; $S_{t}$ : the true fracture surface area; the fracture surface is assumed to exhibit a fractal nature in the scale range from $r_{\min }$ to $\left.r_{\max }\right)$ 
係すると考えられる。したがって，測定される $K_{\mathrm{I} C}$ 值 と $\left[2 \Gamma E /\left(1-v^{2}\right)\right]^{1 / 2}$ との差は fractal toughening によ るものと考えてよいだろう。式 (9)〜 (11) から分かるよ うに，破面やき裂のフラクタル次元が大きく，広い測定 尺度の範囲でフラクタル性が観察される（ $r_{L}$ が小さい) ぜい性材料で，大きな fractal toughening が起こるこ とが予想される。 さらに，式 $(9)$ （11）による $K_{\mathrm{IC}}$ の予 測に用いる $\Gamma$ の值は，いかなる微細組織による強じん 化も含まない，単に新しい表面を作るのに必要な仕事 （表面エネルギー）である。この值が大きいこともぜい 性材料の破壊じん性が大きくなることに結びつくので重 要である。

\section{3 供試材および実験方法}

本研究では酸化物系, 炭化物系および窒化物系セラ ミックスと WC-8\%Co 超硬合金の，15 種類のぜい性材 料を用いて，IF 法による破壊じん性 $\left(K_{C}\right)$ の測定と圧 痕き裂のフラクタル解析を行った。 Table I にぜい性材 料の縦弾性係数（Young's modulus）, 密度，破壊じ ん性 $K_{\mathrm{IC}}$ および平均結晶粒径 (結晶粒径の範囲) ${ }^{28)}$ ３0) を示した．ぜい性材料は表面を粒子径 $3 \mu \mathrm{m}$ のダイヤモ ンド・ペーストを用いて研磨した後， $1 / 4 \mu \mathrm{m}$ のダイヤ モンド・ペーストを用いて仕上げた。文献 ${ }^{31)}$ を参考に して試料の腐食を行った後に, 光学顕微鏡写真あるい は走査型電子顕微鏡写真を撮影し, Fullman ${ }^{32)}$ の方法に よって試料の結晶粒径を求めた. IF 法による破壊じん 性の測定には，ビッカース硬度計あるいはマイクロビッ カース硬度計を用いて荷重 4.9 ～490 N で圧痕き裂を挿 入した。き裂は圧痕の角から発生し，圧痕の部分には 塑性変形が生じると考えられるので, 本研究では圧痕 とその近傍を除いてき裂のフラクタル次元を測定した. 試料の圧痕き裂の光学顕微鏡写真を 400〜1000 倍で, あるいは走査型電子顕微鏡写真を 2000 10 000 倍で 撮影した。庄痕き裂のフラクタル次元 $D$ ”は，これら の写真を用いてボックス・カウント法（Box-counting method $)^{24) \sim 26)}$ によって求めた. Fig. 3 にボックス・カ ウント法による圧痕き裂のフラクタル次元 $D$ ”の測定 を図式的に示した。ボックスの寸法を $r$ ，圧痕き裂を 横切るボックスの個数を $N$ とすると，一般に次の式が 成り立つ. ${ }^{24) ~ 26)}$

$$
N=N_{0} r^{-D^{\prime \prime}}
$$

したがって，き裂の長さ $L は^{24) \sim 27)}$

$$
L=r N=N_{0} r^{1-D^{\prime \prime}}
$$

または，上式の両辺の対数をとって，

$$
\log _{10} L=k+\left(1-D^{\prime \prime}\right) \log _{10} r
$$

ここで, $N_{0}, k\left(=\log _{10} N_{0}\right)$ は定数である．き裂のフ ラクタル次元 $D$ ” は，き裂長さ $L$ と測定尺度 $r$ の值を最 小二乗法によって上式に近似して求めた。

4 破壊じん性 $\boldsymbol{K}_{\boldsymbol{C}}$ とき裂のフラクタル次元 $D^{\prime \prime}$ の評価 $4 \cdot 1$ IF 法による破壊じん性 $K_{C}$ の評価

本研究では IF 法 (Indentation fracture method) ${ }^{20), 21)}$ によってぜい性材料の破壊じん性を求めた。IF 法の荷
重として部分安定化ジルコニア（Y-TZP）と超硬合金 （WC-8\% Co）については $490 \mathrm{~N}$ ，マグネシア（MG12, MG-15）は $4.9 \mathrm{~N}$ ，その他の試料については $9.8 \mathrm{~N}$ を選んだ。一般にこの方法では，ガラスなどのじん性 が低い材料ではメジアンき裂（median crack）が，じ ん性が高い材料では表面型き裂（Palmqvist crack）が 生じることが知られている. ${ }^{20)}$ 破壊じん性 $K_{C}$ は，メジ

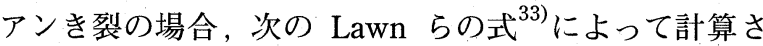
れる。

$$
\begin{aligned}
K_{C} & =0.013(E / H)^{1 / 2}\left(P / c^{3 / 2}\right) \\
& =0.02 E^{0.5} P^{0.5} a^{-0.5}(c / a)^{-1.5}
\end{aligned}
$$

ここで, $c$ はメジアンき裂の半径, $a$ は圧痕の対角線 の半分の長さ, $P$ は荷重, $H$ はビッカース硬さ $(H$ $\left.=0.464 P / a^{2}\right)$ ，そして $E$ は縦弾性係数である. また，表 面型き裂の場合には $K_{C}$ は $l=c-a$ として, 次の新原らの 式 ${ }^{34)}$ にって計算される.

$$
\begin{aligned}
K_{c} & =0.012(E / H)^{2 / 5}(H P / l)^{1 / 2} \\
& =0.011 E^{0.4} P^{0.6} a^{-0.7}(l / a)^{-0.5}
\end{aligned}
$$

本研究では圧痕挿入後の試料を表面から順次研磨し て，压痕き裂の型を調べた。 ${ }^{35)}$ その結果，部分安定化ジ ルコニア $(\mathrm{PSZ})$ ，窒化けい素 $\left(\mathrm{HP}-\mathrm{Si}_{3} \mathrm{~N}_{4}\right)$ と超硬合金 （WC-8\% Co）には表面型き裂が，その他の試料にはメ ジアンき裂が生じることが分かった．Table II に IF 法 による本研究のぜい性材料の破壊じん性值 $K_{C}$ を示し た。なお，各試料の $K_{C}$ 值としては 5 10 点の実験值の 平均を採用した。一種類の炭化けい素（Norton NC430）は結晶粒が約 $1 \mu \mathrm{m}$ 以下の細粒（fine grain）の部 分と数 $10 \mu \mathrm{m}$ 程度の粗粒 (coarse grain) の部分が混 在するので, 各々の部分の $K_{C}$ を別々に測定した。他 の方法で求めた破壊じん性值 $K_{\mathrm{I} C}$ の資料が少ないので 十分な検討はできないが, IF 法による破壊じん性 $K_{C}$ は, 窒化けい素 $\left(\mathrm{HP}-\mathrm{Si}_{3} \mathrm{~N}_{4}\right)$ で $5.2 \mathrm{MPa} \sqrt{\mathrm{m}}$ と製造者 の $K_{\mathrm{I} C}=8.3 \mathrm{MPa} \sqrt{\mathrm{m}}$ より少し小さいことと，炭化けい 素（Norton NC-430）の粗粒部分で $K_{C}=1.7 \mathrm{MPa} \sqrt{\mathrm{m}}$ と 製造者の $K_{\mathrm{I} C}=3.5 \mathrm{MPa} \sqrt{\mathrm{m}}$ の約 $1 / 2$ であることを除け ば， $K_{\mathrm{I} C}$ にほぼ近い值を示すことが分かる．たとえば， WC-8\%Co 超硬合金では $K_{C}=14 \mathrm{MPa} \sqrt{\mathrm{m}}$ で, SENB 試験 片を用いた破壊じん性試験で求めた $K_{\mathrm{I} C}=13.3 \mathrm{MPa} \sqrt{\mathrm{m}}^{28)}$ にほぼ等しく, ソーダ石灰ガラスの $K_{C}=0.60 \mathrm{MPa} \sqrt{\mathrm{m}}$ は Pampuch ${ }^{36)}$ の文献にある $K_{\mathrm{I} C}$ 值 $(0.2 \sim 0.7 \mathrm{MPa} \sqrt{\mathrm{m}})$ や, $\mathrm{Lawn}^{37)}$ の文献の物理定数 $\Gamma=1.75 \mathrm{Jm}^{-2}$ と $E=$ $62 \mathrm{GPa}$ を用いて計算した值 $K_{\mathrm{I} C}=0.68 \mathrm{MPa} \sqrt{\mathrm{m}}$ に近い。

\section{$4 \cdot 2$ 圧痕き裂のフラクタル次元 $D$}

Fig. 4 にぜい性材料の微細組織と圧痕き裂の例を示 した。低破壊じん性のソーダ石灰ガラスでは直線的で長 いき裂がみられる（Fig. 4 (a)）が, 中程度の破壊じん 性をもつアルミナ（SSA-999W）では圧痕の角から屈曲 した微小き裂（Fig. 4 (b)）が生じている.また, 高破 壊じん性の超硬合金の圧痕き裂は, 低倍率の光学顕微 
Table I. The mechanical and physical properties of brittle materials used in this study.

\begin{tabular}{|c|c|c|c|c|}
\hline Materials & $\begin{array}{l}\text { Young's } \\
\text { modulus } \\
(\mathrm{E}, \mathrm{GPa})\end{array}$ & $\begin{array}{c}\mathrm{K}_{\mathrm{IC}} \\
(\mathrm{MPa} \sqrt{\mathrm{m}})\end{array}$ & $\begin{array}{l}\text { Density } \\
\left(\mathrm{g} / \mathrm{cm}^{3}\right)\end{array}$ & $\begin{array}{c}\text { Average grain diameter (m) } \\
\text { (grain size range, m) }\end{array}$ \\
\hline $\mathrm{ZrO}_{2}-3 \mathrm{~mol}: \mathrm{H}_{2} \mathrm{O}_{3} \quad(\mathrm{PSZ})$ & 200 & 6 & 6.05 & $3.0 \times 10^{-7} \quad\left(1.1 \times 10^{-7} \sim 5.7 \times 10^{-7}\right)$ \\
\hline $\mathrm{ZrO}_{2}-11.3 \mathrm{mo} 1 . \% \mathrm{CaO}$ & $150^{13)}$ & - & 5.43 & 1. $2 \times 10^{-5} \quad\left(2.3 \times 10^{-6} \sim 2.6 \times 10^{-5}\right)$ \\
\hline $\mathrm{ZrO}_{2}-6 \mathrm{~mol} . \% \mathrm{Y}_{2} \mathrm{O}_{3}$ & $150^{13)}$ & - & 5.7 & $1.3 \times 10^{-5} \quad\left(1.9 \times 10^{-6} \sim 4.5 \times 10^{-5}\right)$ \\
\hline $\mathrm{ZrO}_{2}-8 \% \mathrm{~mol}_{2} \% \mathrm{Y}_{2} \mathrm{O}_{3}$ & $150^{13)}$ & - & 5.50 & $1.8 \times 10^{-5} \quad\left(4.9 \times 10^{-6} \sim 3.3 \times 10^{-5}\right)$ \\
\hline $\mathrm{Al}_{2} \mathrm{O}_{3} \quad(\mathrm{SSA}-999 \mathrm{~W})$ & 370 & 3.5 & 3.9 & $3.3 \times 10^{-7} \quad\left(9.9 \times 10^{-8} \sim 7.5 \times 10^{-7}\right)$ \\
\hline $\mathrm{Al}_{2} \mathrm{O}_{3}(\mathrm{SSA}-999 \mathrm{H})$ & 380 & 4.5 & 3.95 & $5.8 \times 10^{-6} \quad\left(9.3 \times 10^{-7} \sim 1.5 \times 10^{-5}\right)$ \\
\hline $\mathrm{Al}_{2} \mathrm{O}_{3} \quad(\mathrm{SSA}-\mathrm{S})$ & 350 & 4.0 & 3.9 & 1. $1 \times 10^{-5} \quad\left(1.1 \times 10^{-6} \sim 3.1 \times 10^{-5}\right)$ \\
\hline $\mathrm{MgO}(\mathrm{MG}-12)$ & $210^{13)}$ & - & $3.40<$ & $\left(6.6 \times 10^{-6} \sim 8.5 \times 10^{-5}\right)$ \\
\hline $\operatorname{Mg0}(\mathrm{MG}-15)$ & $210^{13)}$ & - & 3.30 & $\left(3.8 \times 10^{-6} \sim 4.3 \times 10^{-5}\right)$ \\
\hline $\mathrm{SiC}$ (Norton NC-430) & 400 & 3.5 & 3.1 & $\left(3.7 \times 10^{-7} \sim 8.6 \times 10^{-5}\right)$ \\
\hline $\mathrm{SiC}$ (Dense $\mathrm{SiC}$ ) & 470 & - & - & 4. $0 \times 10^{-7} \quad\left(1.2 \times 10^{-7} \sim 1.1 \times 10^{-6}\right)$ \\
\hline $\mathrm{HP}-\mathrm{Si}_{3} \mathrm{~N}_{4}$ & 320 & 8.3 & 3.26 & $\left(2.0 \times 10^{-7} \sim 1.4 \times 10^{-6}\right)$ \\
\hline HP-A1N & $340^{29)}$ & - & $3.3^{29)}$ & $6.0 \times 10^{-6} \quad\left(1.1 \times 10^{-6} \sim 1.1 \times 10^{-5}\right)$ \\
\hline Soda-lime glass & $68^{29)}$ & - & $2.5^{29)}$ & $-\cdots-\cdots$ \\
\hline WC-8\%Co hard metal & $590^{30)}$ & $13.3^{28)}$ & - & $\begin{array}{c}2.1 \times 10^{-6} \quad\left(4.7 \times 10^{-7} \sim 4.3 \times 10^{-6}\right) \\
(\text { WC particles })\end{array}$ \\
\hline
\end{tabular}

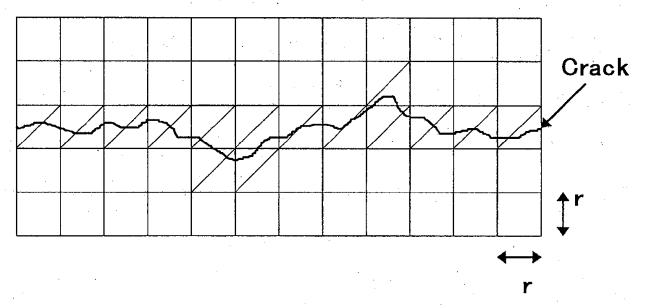

Fig. 3. Schematic illustration of the box-counting method applied to the estimation of the fractal dimension of crack in this study ( $r$ is the size of boxes, and the number of boxes, $N$, intersected by a crack is 15 in this case).

鏡で観察すると直線的に見えるが（Fig. 4 (c))，高倍 率ではき裂は微小な WC 粒子と Co 母相の界面をおもに 伝ぱし，ジグザグな形状をしていることがわかる（Fig. 4 (d)) ${ }^{28)}$ これに対して, 比較的じん性が低い一種類の 炭化けい素の粗粒部分（Norton NC-430）では，低倍 率（Fig. 4 (e)）と高倍率（Fig. 4 (f)）のいずれの写真 に扔いても，圧痕き裂はほぼ直線的である。このよう に, ぜい性材料の破壊じん性と圧痕き裂の形状の複雑さ との間には相関性があるように考えられる。また，き裂 は完全なフラクタルではなく, その形状の複雑さには測
定尺度依存性があるようである。すなわち，圧痕き裂が フラクタル性を示す測定尺度の範囲は, 微細組織の寸 法，たとえば，結晶粒径や第二相粒子寸法などに関係 する. ${ }^{9,}{ }^{11)}$ 本研究では各試料について平均的な形状をも つ 1 個の圧痕き裂について, き裂のフラクタル次元 $D$ ” を求めた. Fig. 5 に圧痕き裂の長さと測定尺度の関係 の一例を示した。な打, $\mathrm{Al}_{2} \mathrm{O}_{3}(\mathrm{SSA}-999 \mathrm{~W})$ ，と HP$\mathrm{Si}_{3} \mathrm{~N}_{4}$ については, 異なる 2 つの倍率で測定した值を， Dauskardt $ら^{9)}$ の方法を用いてまとめて示してある. 図 中には結晶粒径あるいは第二相粒子寸法の範囲とき裂の フラクタル次元の值も示してある，たとえば，圧痕き裂 のフラクタル次元を求めた測定尺度の上限, すなわち, き裂がフラクタル性を示す測定尺度の上限值 $r_{\text {max }}$ は, $\mathrm{Al}_{2} \mathrm{O}_{3}$ (SSA-999W) では $8.4 \times 10^{-7} \mathrm{~m}$ で平均結晶粒径 $3.3 \times 10^{-7} \mathrm{~m}$ に近く，超硬合金では $5.5 \times 10^{-6} \mathrm{~m}$ で WC 粒子の平均粒子径 $2.1 \times 10^{-6} \mathrm{~m}$ に近い. 非晶質のガラ久 を除く他のぜい性材料についても同様のことが言える (Table I， II)。このように, $r_{\max }$ の值は材料の微細組 織の寸法に関連すると考えられる。一方, 松岡 ( $^{8)}$ の研 究によると, き裂がフラクタル性を示す下限值 $r_{\min }$ は 原子間隔の程度と考えられるので, 式 (9)〜 (11) 中の $r_{L}$ を見積もることができる。したがって，ぜい性材料 の縦弾性係数 $E$, ポアッソン比 $v$, 表面エネルギー $\Gamma$ 
Table II. The indentation fracture toughness, $K_{C}$, and the fractal dimension of crack, $D$ ", in brittle materials.

\begin{tabular}{|c|c|c|c|c|}
\hline Materials & $\begin{array}{c}\mathrm{K}_{\mathrm{C}} \\
(\mathrm{MPa} \sqrt{\mathrm{m}})\end{array}$ & $D^{\prime \prime}$ & $\begin{array}{l}\text { Scale range of the } \\
\text { fractal analysis, } r(m)\end{array}$ & $\begin{array}{l}\text { Type of inden- } \\
\text { tation crack }\end{array}$ \\
\hline $\mathrm{ZrO}_{2}-3 \mathrm{~mol} . \% \mathrm{Y}_{2} \mathrm{O}_{3}(\mathrm{PSZ})$ & 5.3 & 1. 18 & $2.7 \times 10^{-8} \sim 8.2 \times 10^{-7}$ & Palmqvist* \\
\hline $\mathrm{ZrO}_{2}-11.3 \mathrm{~mol} . \% \mathrm{CaO}$ & 1.2 & 1. 10 & 2. $7 \times 10^{-7} \sim 1.1 \times 10^{-5}$ & median** \\
\hline $\mathrm{ZrO}_{2}-6 \mathrm{mo} 1 . \% \mathrm{Y}_{2} \mathrm{O}_{3}$ & 2. 0 & 1. 19 & 2. $7 \times 10^{-7} \sim 1.1 \times 10^{-5}$ & median** \\
\hline $\mathrm{ZrO}_{2}-8 \% \mathrm{~mol} . \mathrm{FY}_{2} \mathrm{O}_{3}$ & 1. 1 & 1. 14 & 2. $7 \times 10^{-7} \sim 8.2 \times 10^{-6}$ & median** \\
\hline $\mathrm{Al}_{2} \mathrm{O}_{3} \quad(\mathrm{SSA}-999 \mathrm{~W})$ & 2.9 & 1. 15 & 2. $7 \times 10^{-8} \sim 8.2 \times 10^{-7}$ & median** \\
\hline $\mathrm{Al}_{2} \mathrm{O}_{3} \quad(\mathrm{SSA}-999 \mathrm{H})$ & 3.3 & 1. 19 & 2. $7 \times 10^{-7} \sim 5.5 \times 10^{-6}$ & median** \\
\hline $\mathrm{Al}_{2} \mathrm{O}_{3} \quad(\mathrm{SSA}-\mathrm{S})$ & 3.2 & 1.19 & 2. $7 \times 10^{-7} \sim 1.1 \times 10^{-5}$ & $\operatorname{median} * *$ \\
\hline Mg0 (MG-12) & 1. 2 & 1.09 & 2. $7 \times 10^{-7} \sim 5.5 \times 10^{-6}$ & median*** \\
\hline $\operatorname{MgO}(M G-15)$ & 0.92 & 1.08 & 2. $7 \times 10^{-7} \sim 8.2 \times 10^{-6}$ & median*** \\
\hline $\mathrm{SiC}$ (Norton NC-430) & & & & \\
\hline (coarse grain) & 1. 7 & 1.08 & 2. $7 \times 10^{-7} \sim 5.5 \times 10^{-6}$ & median** \\
\hline (fine grain) & 3.6 & 1. 16 & 2. $7 \times 10^{-7} \sim 5.5 \times 10^{-6}$ & median** \\
\hline Dense $\mathrm{SiC}$ & 2. 3 & 1. 11 & $2.7 \times 10^{-7} \sim 5.5 \times 10^{-6}$ & median** \\
\hline $\mathrm{HP}-\mathrm{Si}_{3} \mathrm{~N}_{4}$ & 5.2 & 1.28 & 2. $7 \times 10^{-8} \sim 8.2 \times 10^{-7}$ & Palmqvist** \\
\hline $\mathrm{HP}-\mathrm{A} 1 \mathrm{~N}$ & 2.0 & 1. 10 & 2. $7 \times 10^{-7} \sim 1.1 \times 10^{-5}$ & median** \\
\hline Soda-lime glass & 0.60 & 1.05 & 2. $7 \times 10^{-7} \sim 4.1 \times 10^{-6}$ & median** \\
\hline WC- $8 \%$ Co hard metal & 14 & 1.27 & $2.7 \times 10^{-7} \sim 5.5 \times 10^{-6}$ & Palmqvist* \\
\hline
\end{tabular}

Indentation load $(\mathrm{P})$; *: $\mathrm{P}=490 \mathrm{~N} ; * *: \mathrm{P}=9.8 \mathrm{~N} ; * * *$ : $\mathrm{P}=4.9 \mathrm{~N}$.

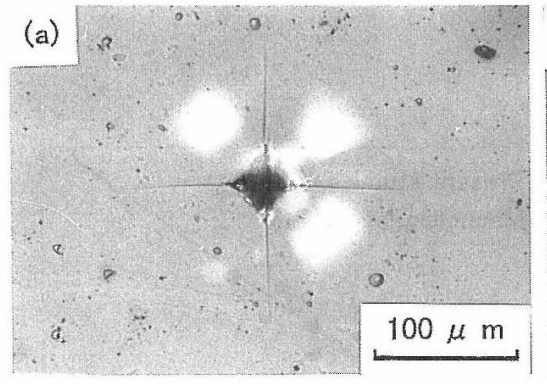

(d)

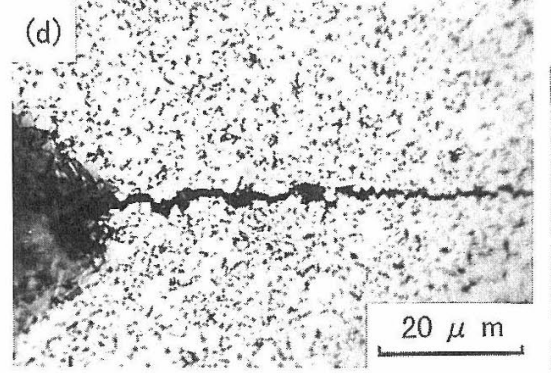

(b)

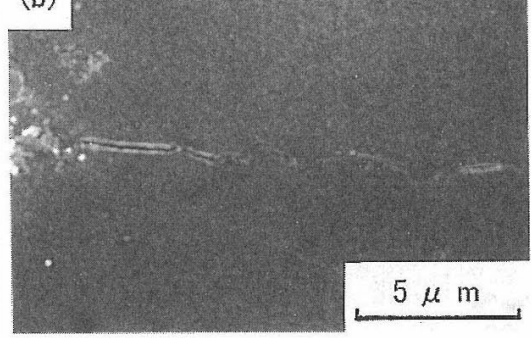

(e)

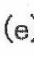

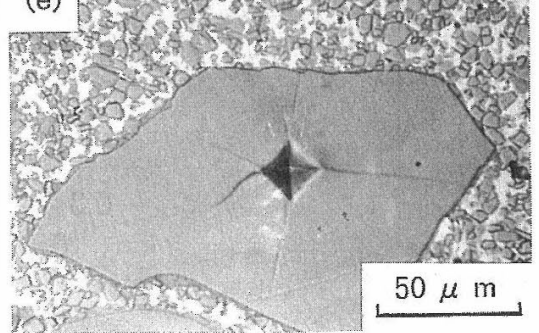

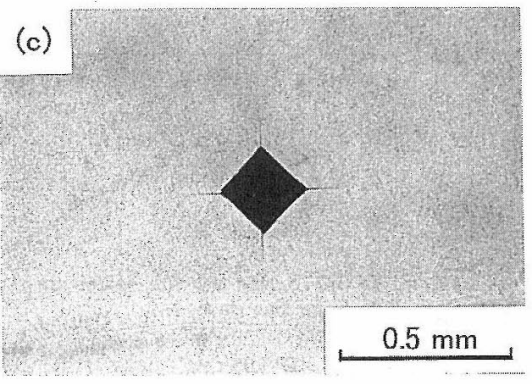

(f)

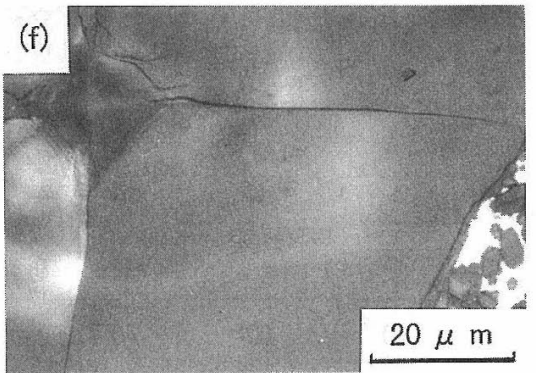

Fig. 4. The indentation cracks observed in brittle materials.
(a) Soda-lime glass
(b) $\mathrm{Al}_{2} \mathrm{O}_{3}$ (SSA-999W)
(c),(d) WC- $8 \%$ Co hard metal
(e), (f) $\mathrm{SiC}$ (Norton NC-430) 
が既知ならば，き裂のフラクタル次元 $D$ ”から破壊じん 性 $K_{\mathrm{I} C}$ の大きさの程度を式 (9)〜 (11) から推定すること ができる。

\section{$4 \cdot 3$ 破壊じん性 $K_{C}$ とき裂のフラクタル次元 D” の関係}

Table I に示したように，本研究のぜい性材料におい ては，き裂のフラクタル次元 $D$ ” の増加とともに IF 法 による破壊じん性 $K_{C}$ は増加する。この実験結果は, Mecholsky らのアルミナとガラス・セラミックスに関 する研究報告 ${ }^{11)}$ と一致する。しかし，式 (9)〜(11) に 示したように, $K_{C}$ の $D$ ” 依存性は Mecholsky ら ${ }^{11)}$ Milman $~{ }^{12)}$ の結果とは異なると考えられる。 Fig. 6 にぜい性材料における $\ln K_{C}$ とき裂のフラクタル次元 の少数部分 $D "-1$ との関係を示す.ただし, 破壊じん 性に及ぼす塑性変形の影響が無視できない超硬合金 $(\mathrm{WC}-8 \% \mathrm{Co})^{28)}$ と一般に転移じん化の影響が考えられ る部分安定化ジルコニア（PSZ）の実験結果は除外し た。これらの材料については，何らかの方法で破面の フラクタル性による破壊じん性への寄与分のみを分離 して評価すべきであるが，現時点では困難であり，さ らに研究が必要である。図中には Mecholsky ら ${ }^{11)}$ が 求めた破壊じん性 $K_{\mathrm{I} C}$ と slit island 法による破面のフラ クタル次元 $D^{\prime}$ の実験結果も示してある.ここで, $D^{\prime}$ とき裂のフラクタル次元は同一材料においては等しい （ $D^{\prime \prime}=D^{\prime} ）$ と仮定した。 また，Mecholsky ら ${ }^{11)}$ の slit island 法による「島」の最大面積は $5.0 \times 10^{-9} \mathrm{~m}^{2}$ なの で，彼らのフラクタル解析における $r_{\max }$ の值は 1.0 $\times 10^{-4} \mathrm{~m}$ 以下と考えられる.すべての実験点はつぎの式 で近似される。

$$
\ln K_{c}=-0.116+5.78\left(D^{\prime \prime}-1\right) \quad(\gamma=0.8081)(17)
$$

ここで, $\gamma$ は相関係数である. 上式から $r_{L}$ の值を求め

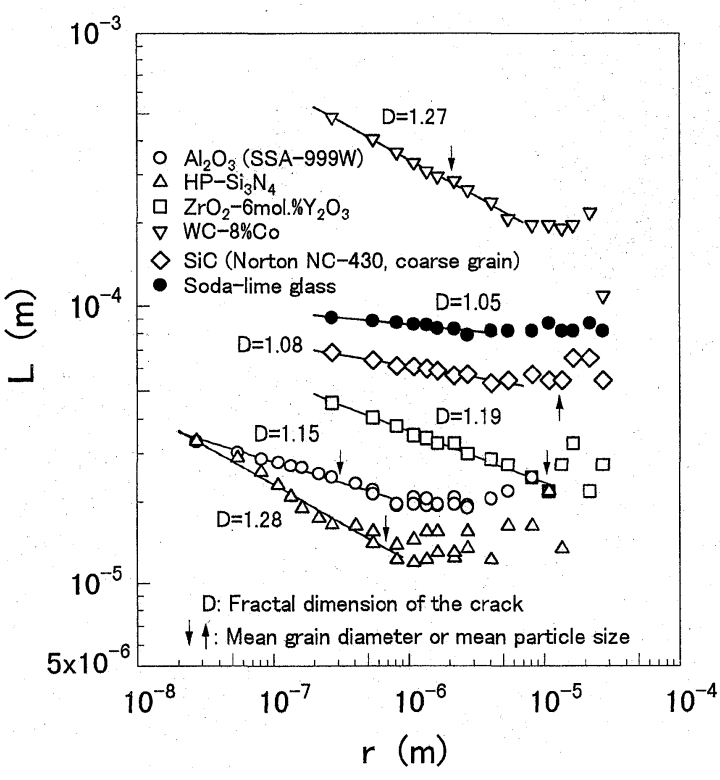

Fig. 5. Relationship between the length of indentation crack, $L$, and the scale length of fractal analysis, $r$, in brittle materials.
ると， $r_{L}=1.9 \times 10^{-4} \mathrm{~m}$ となった。前述のように， $r_{L}$ は き裂がフラクタル性を示す測定尺度の下限值 $r_{\min }$ と上 限值 $r_{\max }$ の比 $r_{\min } / r_{\max }$ である。 $r_{\min }$ は原子間隔の程度 と考えられるので ${ }^{8)} r_{\min } \fallingdotseq 1.0 \times 10^{-9} \mathrm{~m}, r_{\max }$ は結晶粒径 のような微細組織の寸法に関係するので $r_{\max }=5.0 \times$ $10^{-6} \sim 1.0 \times 10^{-4} \mathrm{~m}$ とすると, $r_{L}=1.0 \times 10^{-5} \sim 2.0 \times 10^{-4}$ と見積もることができる。上述の $r_{L}$ の実験值はこの計 算值の上限に近い. また, $D ”=1$ としたときの $K_{C}$ 値 $1.2 \mathrm{MPa} \sqrt{\mathrm{m}}$ はガラスの $K_{\mathrm{IC}}$ 值 $(0.2 \sim 0.7 \mathrm{MPa} \sqrt{\mathrm{m}})^{36)}$ よりも少し大きい. これは式 (9)～(11) からもわかるよ うに，実験点のばらつきだけでなく，材料によって表面 エネルギー $\Gamma$ や弾性定数 $E, v$ の值が異なることにも関 係すると考えられる，前章で述べたように，r $r_{L}$ はぜい 性材料での fractal toughening の程度を表し， $r_{L}$ が小さ いほどじん化が大きくなる。さらに，「は単に表面を形 成するのに必要な仕事（表面エネルギー）であって，本 研究では他の微細組織因子の影響を含まないと仮定され ている，したがって，き裂あるいは破面のフラクタル次 元 $\left(D, D^{\prime}, D^{\prime \prime}\right)$ と， $r_{L}$ や $\Gamma$ の信頼できる值を用いれ ば, 式 (9)〜(11) からぜい性材料の破壊じん性 $K_{\mathrm{I} C}$ のお およその值を予測することができる。.さらに, Hull ${ }^{15), 16)}$ が指摘するように，巨視的にはモードＩの破面でも，モ ードII，モードIIIという他の負荷様式が加わることで微 視的な破面やき裂形状の複雑さが生じるが，他の負荷 様式が破面形態にどの程度影響を及ぼすかは材料特性 に依存する。したがって，材料の破面形成の機構と破 面や微細組織のフラクタル性との間には定量的な関連 があるものと考えられる。この点については現在検討中 である。

\section{5 結言}

本研究ではフラクタル幾何学に基づいてぜい性材料に おける破面およびき裂形状の解析を行い，破面およびき 裂のフラクタル次元 $\left(D, D^{\prime}, D^{\prime \prime}\right)$ と破壊じん性 $K_{\mathrm{I} C}$ を

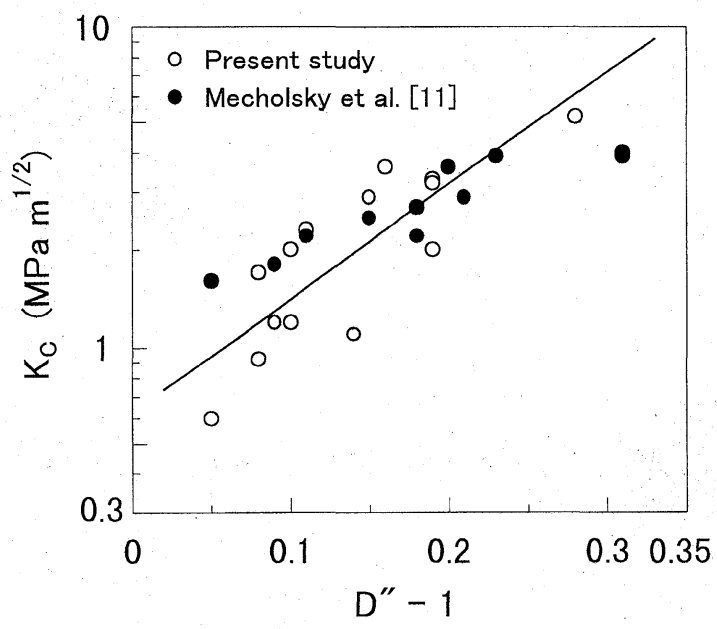

Fig. 6. Relationship between the indentation fracture toughness, $K_{C}$, and the fractional part of the fractal dimension of crack or the fracture surface, $D$ "- 1 , in brittle materials. 
関連づける理論式を導き出した。つぎに, 酸化物系, 窒 化物系, 炭化物系のセラミックス, 超硬合金およびソー ダ石灰ガラスを用いて, IF 法によって破壊じん性を求 め, ボックス・カウント法によって圧痕き裂のフラクタ ル次元 $D$ ”を評価して, 両者の関係について検討した. 以下に得られた結果を要約する.

（1）フララタル幾何学に基づく理論解析の結果, 破壊 じん性 $K_{\mathrm{I} C}$ とき裂のフラクタル次元 $D$ ” との間には, $\ln K_{\mathrm{I} C}=1 / 2\left\{\ln \left[2 \Gamma E /\left(1-v^{2}\right)\right]-\left(D^{\prime \prime}-1\right) \ln r_{L}\right\}$ の関係が あることが分かった．ここで，「は単に新しい表面を作 るのに必要な仕事（表面エネルギー）であり，E は縦弾 性係数, $v$ はポアッソン比, そして $r_{L}$ はき裂がフラクタ ル性を示す測定尺度の下限值 $r_{\text {min }}$ と上限值 $r_{\text {max }}$ の比 $r_{\min } / r_{\max }$ である.上式の第 2 項 $\left(-0.5\left(D^{\prime \prime}-1\right) \ln r_{L}\right)$ は き裂形状のフラクタル性によるじん化（fractal toughening）を表す。ぜい性材料では $r_{\min }$ は原子間隔の程度で, $r_{\text {max }}$ は結晶粒径などの微細組織の寸法あるいはき裂や破 面の寸法に関連する.

（2）本研究のぜい性材料では，圧痕き裂のフラクタル 次元 $D$ "は 1.05 (ソーダ石灰ガラス) から 1.28 (HP$\left.\mathrm{Si}_{3} \mathrm{~N}_{4}\right)$ の範囲にあった. IF 法による破壊じん性 $K_{C}$ は, き裂のフラクタル次元の増加とともに増加した．塑性変 形の影響が無視できない超硬合金（WC- $8 \% \mathrm{Co}$ ) と，転移 じん化が起こる部分安定化ジルコニア（PSZ）で大きな $K_{C}$ 值が得られた.これらの材料における破壊じん性へ の破面のフラクタル性の寄与を評価するには，さらに研 究が必要である。

本研究のき裂のフラクタル解析は $2.7 \times 10^{-8} \sim 1.1 \times 10^{-5} \mathrm{~m}$ の測定尺度の範囲で行われ，フラクタル解析の上限值 $r_{\text {max }}$ は結晶粒径や第二相粒子のような微細組織の寸法に 関係づけられた。

(3) 本研究の実験結果（超硬合金と部分安定化ジル コニアを除く）と Mecholsky らの実験結果を上式にあ てはめて） $r_{L}=1.9 \times 10^{-4}$ および $D ”=1$ に対して $K_{\mathrm{I} C}$ $=1.2 \mathrm{MPa} \sqrt{\mathrm{m}}$ が得られた. $r_{L}$ の值は $r_{\min }$ と $r_{\max }$ から見 積もられた值 $\left(10^{-5} \sim 10^{-3}\right)$ の範囲にあったが， $D ”=1$ にたいする $K_{\mathrm{I} C}$ 值はガラスの $K_{\mathrm{I} C}$ 值よりも少し大きかっ た．破面やき裂のフラクタル次元 $\left(D, D^{\prime}, D^{\prime \prime}\right), r_{L}$ や $\Gamma$ の信頼できる值を用いれば，上式から理論的にぜい 性材料のお打よその破壊じん性值を予測することがで きる。

最後に，本研究で用いた各種セラミックス材料を提供 して戴いた株) 東芝金属セラミックス材料研究所，(株)ニッ カトーならびに東洋曹達工業 (株), WC- $8 \%$ Co 超硬合金を 提供して下さった小林工業(株)，および試料の走査型電子 顕微鏡による観察をして戴いた秋田工業技術センターの 木村光彦氏に心から感謝致します。

\section{参 考 文 献}

1) B. B. Mandelbrot, D. E. Passoja and A. J. Paullay, Nature, 308, 721 (1984).

2) E. Hornbogen, Z. Metallkd., 78, 622 (1987).
3 ) M. Tanaka and H. Iizuka, Z. Metallkd., 82, 442 (1991).

4) P. Streitenberger, D. Förster, G. Kolbe and P. Veit, Scripta Metall. Mater., 33, 541 (1995).

$5)$ E. E. Underwood and K. Banerji, Mater. Sci. Eng., 30, 1 (1986).

6) C. S. Pande, L. E. Richards, N. Louat, B. D. Dempsey and A. J. Schwoeble, Acta Metall., 35, 1633 (1987).

7 ) K. Ishikawa, T. Ogata and K. Nagai, J. Mater. Sci. Lett., 8, 1326 (1989).

$8)$ S. Matsuoka, H. Sumiyoshi and K. Ishikawa, Trans. Japan Soc. Mech. Eng., 56, 2091 (1990).

$9)$ R. H. Dauskardt, F. Haubensak and R. O. Ritchie, Acta Metall. Mater., 38, 143 (1990).

10) Z. G. Wang, D. L. Chen, X. X. Jiang, S. H. Ai and C. H. Shih, Scripta Metall., 22, 827 (1988).

11) J. J. Mecholsky, D. E. Passoja and K. S. Feinberg-Ringel, J. Am. Ceram. Soc., 72, 60 (1989).

12) V. Y. Milman, N. A. Stelmashenko and R. Blumenfeld, Progr. Mater. Sci., 38, 425 (1994).

13) W. D. Kingery, H. K. Bowen and D. R. Uhlmann, "Introduction to Ceramics”, 2nd Edition, p.796 (1976) J. Wiley.

14) D. W. Richerson, "Modern Ceramic Engineering", 2nd Edition, p.731 (1992) Marcel Dekker.

15) D. Hull, Int. J. Fract., 70, 59 (1995).

16) D. Hull, J. Mater. Sci. Lett., 15, 651 (1996).

17) M. Tanaka, J. Mater. Sci., 27, 4717 (1992).

18) M. Tanaka, Z. Metallkd., 84, 697 (1993).

19) M. Tanaka, J. Mater. Sci., 28, 5753 (1993).

20）西田 孝, 安田栄一, “セラミックスの機械的性質の評価”, p.63（1986）日刊工業新聞社.

21) K. Niihara, R. Morena and D. P. H. Hasselman, "Fracture Mechanics of Ceramics”, Vol. 5, edited by R. C. Bradt, A. G. Evans, D. P. H. Hasselman and F. F. Lange, p. 97 (1983) Plenum Press.

22) Z. Li, A. Ghosh, A. S. Kobayashi and R. C. Bradt, J. Am. Ceram. Soc., 74, 889 (1991).

23) S. Srinivasan and R. O. Scattergood, J. Am. Ceram. Soc., 74, 887 (1991).

24) B. B. Mandelbrot 著, 広中平祐訳, “フラクタル幾何学”, p.42（1985）日経サイエンス.

25) H. Takayasu, "Fractals in the Physical Sciences", p.11 (1990) Manchester University Press.

26）石村貞夫, 石村園子, “フラクタル数学”, p.240（1990） 東京図書.

27) A. M. Gokhale, W. J. Drury and S. Mishra, "Fractography of Modern Engineering Materials : Composites and Metals", Second Volume, ASTM STP 1203, edited by J. E. Masters and L. N. Gilbertson, p.3 (1993) American Society for Testing and Materials.

28) H. lizuka and M. Tanaka, J. Mater. Sci., 26, 4394 (1991).

29） A. Kelly 著, 村上陽太郎訳, “複合材料”, p.221（1971） 丸善. 
30）技術資料「金属材料の弾性䋆数」出版分科会編，“技術資 料・金属材料の弾性係数,” p.227（1980）日本機械学会.

31） G. Petzow 著, 松村源太郎訳, “金属腐食技術”, p.56 (1976) アグネ.

32) R. L. Fullman, Trans. AIME, 197, 447 (1953).

33) B. R. Lawn, A. G. Evans and D. B. Marshall, J. Am. Ceram. Soc., 63, 574 (1980).
34) K. Niihara, R. Morena and D. P. H. Hasselman, J. Mater. Sci. Lett., 1, 13 (1982).

35) M. T. Laugier, J, Mater. Sic. Lett., 6, 897 (1987).

36) R. Pampuch, "Constitution and Properties of Ceramic Materials”, p.68 (1991) Elsevier.

37) B. R. Lawn, "Fracture of Brittle Solids", 2nd edition, p.9 (1993) Cambridge University Press. 